\title{
RISK ASSESSMENT IN RENEWABLE ENERGY PRODUCTION FROM AGRICULTURE BIOMASS IN LATVIA
}

\author{
Baiba Rivza*, Sandija Rivza*, and Peteris Rivza** \\ * Faculty of Economics, Latvia University of Agriculture, Jelgava, LV-3001, LATVIA \\ baiba.rivza@\|lu.Iv \\ ** Faculty of Information Technologies, Latvia University of Agriculture, Jelgava, LV-3001, LATVIA \\ Contributed by Baiba Rivža
}

\begin{abstract}
The concepts ,,risk”, ,crisis”, ,,danger" have become commonly used and recognised in various fields of entrepreneurship, governance, agriculture and environment protection. Risk management and risk evaluation nowadays has not only theoretical, but also practical application. Risk assessment is an important factor for successful and sustainable entrepreneurship of bioenergy production, which has become one of the priorities in the energy sector of Latvia - promotion of the use of renewable energy is included as one of the strategic goals for both European Union (EU) and Latvia. The present research focuses on risk assessment and choice of risk management alternatives in renewable energy production form agriculture biomass, since this type of energy is viewed as a perspective source for renewable energy production in Latvia. This field of energy production in Latvia is rather new and scantily explored, and therefore there are many risk factors that arise in different stages of energy production, starting with planning and building of a bioreactor and ending with production and further use and distribution of energy. A risk assessment module for renewable energy production made using Analytic Network Process (ANP) software is described in the paper.
\end{abstract}

Key words: Analytic Network Process (ANP), renewable energy, risk assessment, Latvia.

\section{INTRODUCTION}

Following world tendencies, renewable energy production in Latvia has received increasing interest. Currently, most of the electricity from renewable resources is produced from hydropower plants, while $1 \%$ of the electricity in Latvia is produced by cogeneration of biomass (Anonims, 2010). Thus, biomass is a perspective source for increasing renewable energy production in Latvia. The development of cogeneration plants is largely encouraged by funding from EU structural funds, the Cohesion fund and the European Agriculture fund for rural development. As production of biogas from agriculture biomass is a new field of energy production in Latvia, there is a lack of practically tested knowledge and experienced service providers. There are many crucial issues related to different stages of production of biogas production and management of processes that require analysis of risk. In this article we analyse risks that the producers of biogas are facing, define risk management alternatives and adapt a risk management cycle for this type of production.

This is a revised and an extended version of an article that is based on the paper „Risk Assessment in Renewable Energy Production Using ANP" previously presented in the Proceedings of the 11th International Symposium of the Analytic Hierarchy Process in Naples, Italy, 2011 (Rivza, 2011).

\section{THEORIES / METHODS}

Even though the activities of an individual have always been subject to risk, the understanding of risk and its role in society become an issue of theoretical and practical importance at the turn of the $20^{\text {th }}$ and $21^{\text {st }}$ centuries, as portrayed in the ideas of two sociologists - Ulrich Beck (1999) and Anthony Giddens (2002).

Interest in risk management has expanded, and an increasing number of studies have applied risk evaluation and risk management methods. Analysis of these studies show that various authors have different understanding of the definition and parameters of the term "risk". However, all concepts of risk contain one and the same precondition: the consequence of the human activities. In any situation an individual, an organisation, or the whole society have several ways of choosing the next move (including doing nothing) and each of them causes either negative or positive consequences (Renn, 2008). Analysis of the scientific literature on the notion of risk: (Hardaker and Huirne, 2004; Pettere un Voronova, 2004; Arhipova, 2005; Šuškeviča, 2005; Renn, 2008; Baoding, 2011; Anonymous, n.d.); and on the principles of definitions of risks, described by the German sociologist Ortwin Renn (Renn, 2008) - the authors suggest the following definition of "risk": "Risk is the multiplication of the probability of an event and the significance of potentially unfavorable consequences." 
Although researchers of the Latvia University of Agriculture have experience in working with risk determination and assessment issues in various fields of agriculture, veterinary medicine, food science, etc. (Rivža, 2004; Anonīms, 2005; Anonīms, 2007), the field of renewable energy production is rather new and insufficiently explored. Therefore, we need to adopt the experience of other countries, for example, USA (Rausser and Papineau, 2008), UK (Anonymous, 2010) and organisations such as the United Nations Environment Programme (Anonymous, 2004a). In this study, the Analytic Network Process (ANP) was used for risk assessment in renewable energy production, as it allows to include various factors and criteria - tangible and intangible (Saaty, 2010), which are characteristic of risk assessment.

The ANP is a general theory of relative measurement used to derive composite priority ratio scales from individual ratio scales that represent relative measurements of the influence of elements that interact with respect to control criteria. Through its supermatrix, whose elements are themselves matrices of column priorities, the ANP captures the outcome of dependence and feedback within and between clusters of elements. The Analytic Hierarchy Process (AHP) with its dependence assumptions on clusters and elements is a special case of the ANP. The ANP is a new and an essential phase in decision making, neglected so far because of the linear structures used in traditional approaches and their inability to deal with feedback in order to choose alternatives not simply according to attributes and criteria, but also according to their consequences, which may be positive or negative - an essential and so far missing consideration in decision making (Saaty, 1999). Most commonly, and also in this paper, expert interviews are used for decision making in application of ANP and AHP methods.

\section{RESULTS AND DISCUSSION}

The present research focuses on risk assessment in production of renewable energy from biogas in cogeneration. A literature review of risk management for renewable energy production showed that risks can mainly by classified by the cause of risk. Dominant and specific risk groups can be observed. Technological, environment, legislative, financial and investment risks (Anonymous, 2004b; Froggatt and Lhan, 2010; Ferraris, n.d.; Olivier, n.d.) are frequently described in risk management studies of this certain field. Risk groups, such as social, macro-economical, resource, short and long-term operative risks and reputation risks (Anonymous, 2004a; Aragonés-Beltrán and PastorFerrando, 2009; Froggatt and Lhan, 2010), are more specific and not as common as the previously mentioned risk groups. Based on this review the risks were divided into five groups or clusters: personnel, production, property, environment, and legislative risks. They were evaluated by the ability to use one of three strategies - risk reduction, risk transfer, or risk undertaking strategy. The strategies were also chosen based on the literature review, which showed that risk management in this field is generally performed by five general strategies: evasion, reduction, transfer, undertaking and diversification (Sparrow, 2000; Pettere and
Voronova, 2003; Anonymous, 2004; Špog̣is, 2005; Trigilio, 2006; Olivier, n.d.). However, regarding the specific characteristics of the risk groups and application of the ANP method, three of five alternatives - risk reduction, risk transfer, or risk undertaking strategy — were considered as most suitable.

In the ANP module, each of the five groups includes several risks (Table 1). The group of personnel risks consisted of three risks that are connected with the responsibility, qualification and experience of employees and adherence of work safety on the production site. Production risks form the biggest group in our risk classification, as they include six risks that cover the bioenergy production process, starting from the preparation of biomass and its quality to supply management, processing of biomass in the cogeneration process and the further use of electricity and heat. Property risks refer to the security and sustainability of the property that is used in the production. Environment risks mentioned in this assessment are closely linked with the process phases of energy production - storage and transportation of biomass, storage of digestate after the production of energy and use of the digestate in fertilisation of fields. The last group is legislative risks; these external risks arise from the actions of governmental institutions - Ministry of Economy, municipalities etc.

Table 1

CLASSIFICATION OF ACCESSED RISKS

\begin{tabular}{|c|c|}
\hline Risk group (cluster) & Risk \\
\hline 1. Personnel & $\begin{array}{l}\text { 1.1.Responsibility of the personnel } \\
\text { 1.2. Qualification and experience } \\
\text { 1.3. Work safety }\end{array}$ \\
\hline 2. Production & $\begin{array}{l}\text { 2.1. Quality of biomass } \\
\text { 2.2. Stability of the microbiological processes in the } \\
\text { bioreactor } \\
\text { 2.3. Regular supply of biomass } \\
\text { 2.4. Connection with the state electricity network } \\
\text { 2.5. Utilisation possibilities of the produced heat and } \\
\text { their stability } \\
\text { 2.6. Accessibility of service for technical equipment }\end{array}$ \\
\hline 3. Property & $\begin{array}{l}\text { 3.1. The outer security of the bioreactor and other } \\
\text { production facilities } \\
\text { 3.2. Credit risk } \\
\text { 3.3. Fire security }\end{array}$ \\
\hline 4. Environment & $\begin{array}{l}\text { 4.1. Storage of digestate } \\
\text { 4.2. Transportation of biomass } \\
\text { 4.3. Storage of biomass } \\
\text { 4.4. The use of digestate in fertilisation of fields }\end{array}$ \\
\hline 5. Legislative & $\begin{array}{l}\text { 5.1. Changes in energy policy } \\
\text { 5.2. Changes in the purchase tariffs }\end{array}$ \\
\hline
\end{tabular}

Besides the five risk groups or clusters, the current risk assessment module includes three alternatives at the same level of the risk groups: to reduce risks, to transfer risks, and to undertake risks. These alternatives illustrate the possible choices in risk management. The further analysis using the ANP method was conducted using Superdecisions software, to identify the alternative that would be the best choice for each of the risks and risk groups (as an average value of all risks in the group). Figure 1 shows the connections (influences) between risk groups and alternatives. An 


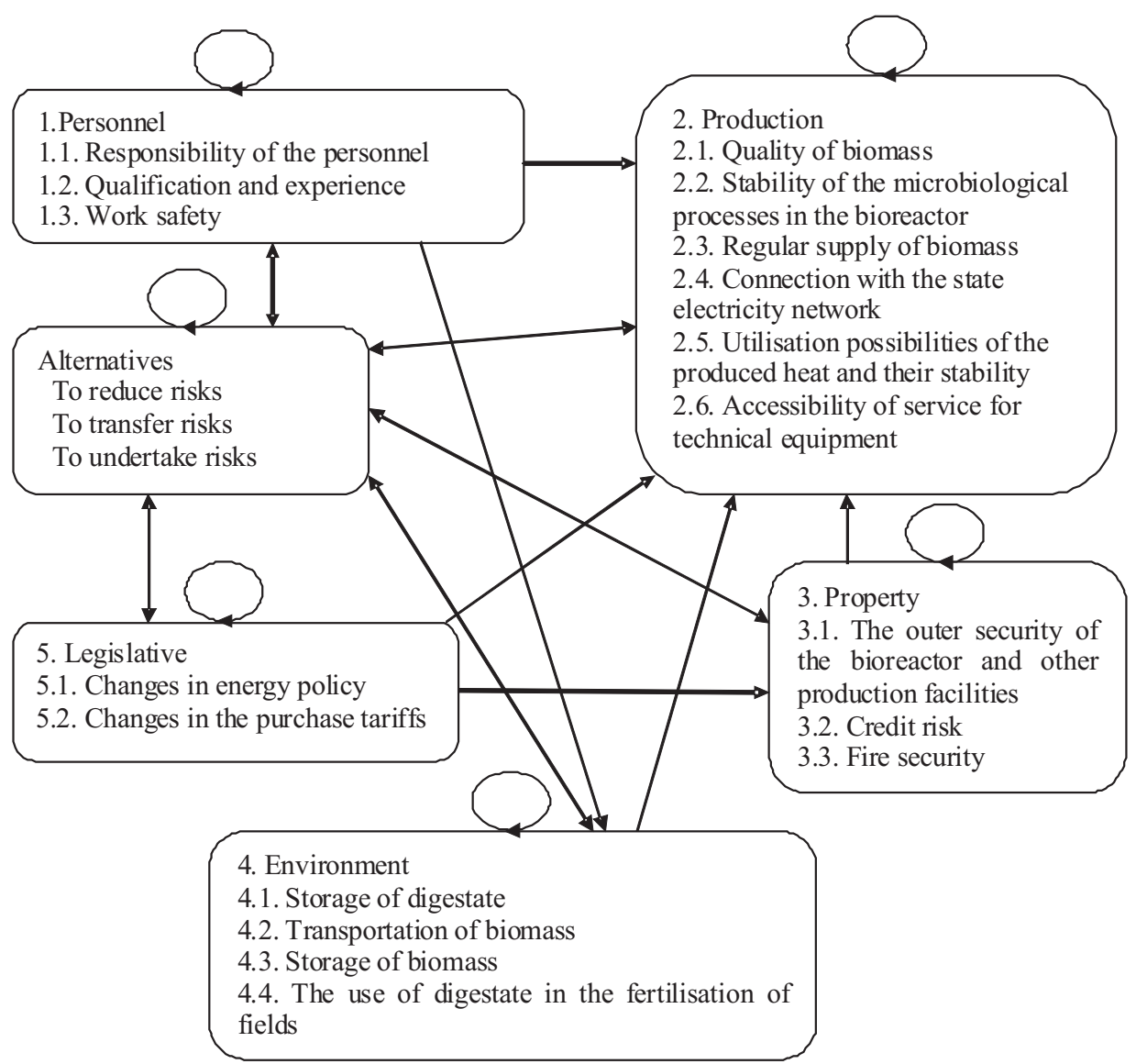

Fig. 1. Graph of influences describing relations between risk groups. arrow from one cluster to another shows that all or some elements in the first cluster influence all or some elements in the second cluster, but the reflexive loops (internal cycles) correspond to mutual influence between the elements in one cluster.

Figure 1 shows that production risks are most influenced by the other risk groups - personnel risks (regarding responsibility and qualification of workers and impact of these qualities on biomass preparation, regular supply and management of the cogeneration processes), legislative risks (in terms of possibilities to connect to the state electricity network and to utilise the produced heat), environment risks (as the need to adhere to environment protection regulations in the production process) and property risk (in terms of production site fire-safety and outer security, recoupment/credit risk, also affected by purchase tariffs).

All risk groups and alternatives are interdependent — one of the elements in the cluster influences other elements in the same cluster, for example the risk ,changes in the energy policy" in the cluster ,legislative risks" influences the risk ,,changes in the purchase tariffs", as the purchase tariffs are set by the government and therefore influenced by political decisions.

After the determination of influences, clusters and nodes of related risks were evaluated. In ANP an intensity of influence is estimated by experts using pairwise comparison and the fundamental ratio scale (Saaty, 2001). Pairwise comparison is the most universal method of measurement, as it can be applied without the use of scales scales and standards, in which is particular important in estimation of intangible attributes. Comparing two objects with respect to a common attribute (criterion, property), the expert estimates a relative preference of one object over another, choosing a suitable estimation from the fundamental scale (Andreichicova and Radyshevskaya, 2007). In this case the importance or significance of one element over another element is measured.

The results of the performed assessment show (Fig. 2) that the alternative that was rated as the best choice for risk management was to reduce risks (average value of all risk groups is 0.21 ). The transfer of risk shows a high variability (average: 0.176; min: 0.023; $\max : 0.522$ ) as the best choice, indicating that this alternative is highly suggested for certain risks or risk groups and avoidable or impossible for other.

Figure 3 allows to identify the suitability of alternatives to risk groups. Legislative risks, according to the assesment (0.209), are not highly managable in terms of transfer or reduction; these risks can be undertaken and attention can be paid to changes, for example, perhaps by participation in the drafting process of new government regulations that include tariff changes, but there are minor possibilities of affecting these processes from the energy producer point of view.

Also in the production risks group the alternative of undertaking risks (2.6) was ranked high meaning that not all problems in production process can be forecast and reduced, yet ,to reduce risks" is the highest ranking alternative (3.18) in this group, showing the large need of control in the production procesess. Personnel and Environment risks 

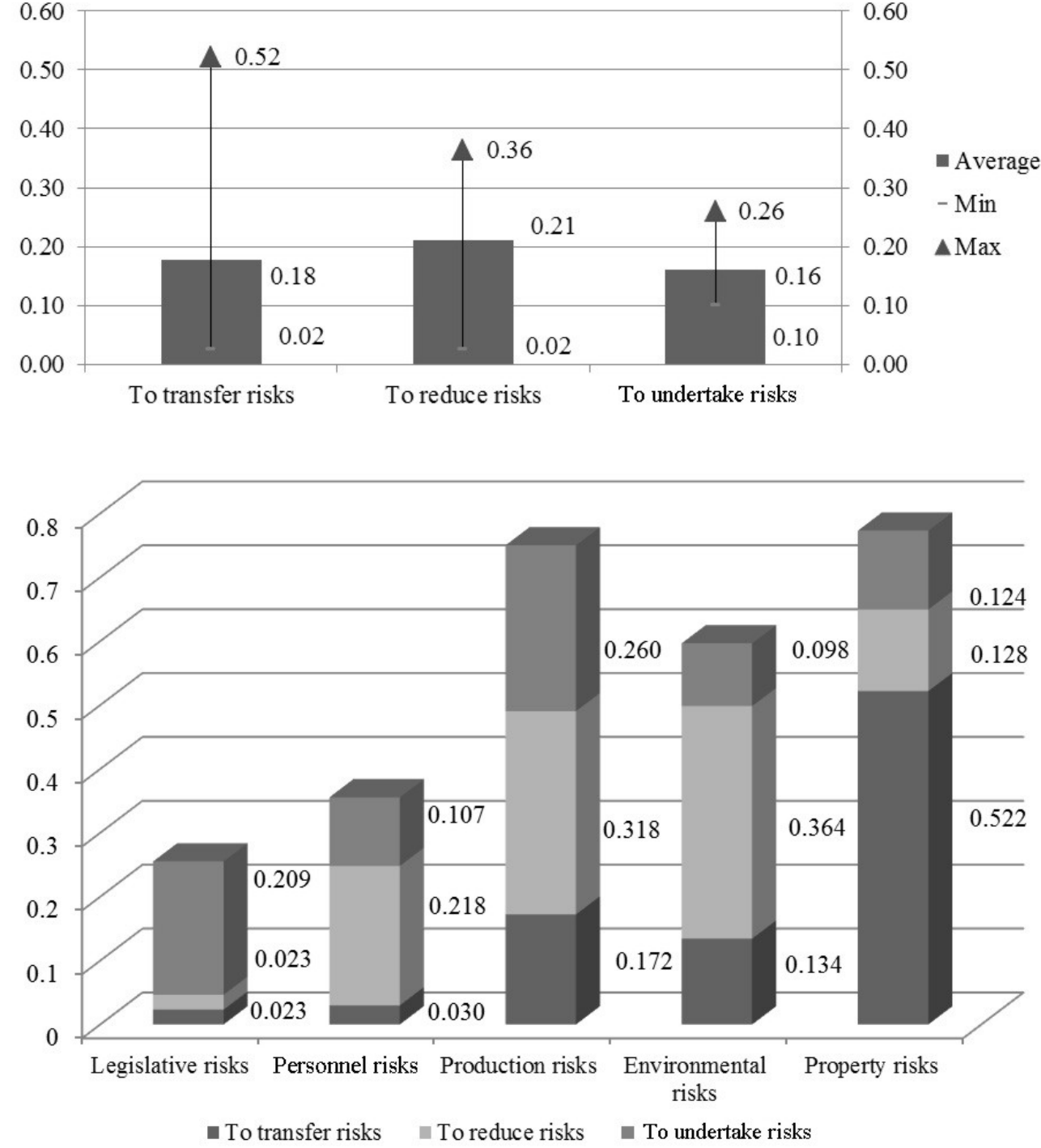

Fig. 2. Assessment of alternatives in risk reduction.
Fig. 3. Choice of alternatives within the risk groups. were considered to be low ( 0.218 and 3.64 , respectively), but property risks were suggested to be transferred (0.522), for example with insurance, yet some of these risks could be reduced or undertaken.

In conclusion:

1) The sector of agriculture production is subject to various risks. Therefore, comprehensive risk determination and classification are important preconditions to successful and meaningful risk management.

2) The use of ANP in risk management gives an opportunity to perform risk assessment by including tangible and intangible factors, and to evaluate various relationships between risks and alternatives, making it a valuable tool for risk assessment.

3) The current risk assessment in renewable energy production showed that most of the risks were considered to be reduced (personnel, production and environment risks) or transferred (property risks in particular), yet there were several risks, mainly in the group of legislative risks, that could be only undertaken i.e. taken into further consideration.

\section{ACKNOWLEDGEMENTS}

The preparation of the paper was supported by the project „, Capacity Building of Latvian Academy of Sciences and Latvian Academy of Agricultural and Forestry Sciences and Elaboration of International Project Proposals", Agreement No. 2010/0294/2DP/2.1.1.2.0/10/APIA/VIAA/009, Project No. 009/2112.

\section{REFERENCES}

Andreichicova, O.N., Radyshevskaya, T.N. (2007). Application of the Analytic Network Process to a forecasting of oral health. In: Proceedings of the International Symposium on the Analytic Hierarchy Process. Vina Del Mar, Chile.p. 11. Available at:

http://www.isahp.org/2007Proceedings/Papers/Working\%20Sessions/ Medical\%20Area/Forecasting\%20of\%20Oreal\%20Health.pdf

Anonīms (2005). Riski lauksaimniecībā un privātajā mežsaimniecībā [Risks in Agriculture and Private Forestry]. Jelgava: LLU, 47.-59. 1pp. (in Latvian).

Anonīms (2007). Lauksaimniecības un pārtikas risku vadīšana [Monitoring of Agricultural and Food-related Risks]. Jelgava: LLU, 41.-51. lpp. (in Latvian).

Anonīms (2009). Latvijas Republikas rīcība atjaunojamās enerǵijas jomā Eiropas Parlamenta un Padomes 2009. gada 23. aprīḷa direktīvas 2009/28/EK par atjaunojamo energoresursu izmantošanas veicināšanu un 
ar ko groza un sekojoši atcel Direktīvas 2001/77/EK un 2003/30/EK ieviešanai līdz 2020. gadam. Informatīvais ziņojums. LR Satiksmes ministrija [The action of the Republic of Latvia in the field of renewable energy according to the implementation of the Directive 2009/28/EC of the European Parliament and the Council of 23 April 2009 on the promotion of the use of energy from renewable sources and amending and subsequently repealing Directives 2001/77/EC and 2003/30/EC till the year 2020] (in Latvian). Available at:

www.sam.gov.lv/images/modules/.../item_551_SAMzino_050606.doc

Anonīms (2010). Atjaunojamās enerğijas likums. Ekonomikas ministrija. Available at:

www.em.gov.lv/images/modules/items/EMLik_150910_AEL.doc

Anonymous (2004a). Financial Risk Management Instruments for Renewable Energy Projects. Summary document. United Nations Environment Programme. Oxford, UK: Words and Publications. 52 pp.

Anonymous (2004b). Guide to Risk Management. Australian Capital Territory Insurance Authority.

Available at: http://www.treasury.act.gov.au/actia/Risk.htm

Anonymous (2010). Sustainable Energy Security: Strategic risks and opportunities for business, White paper. LLOID`S $360^{\circ}$ Risk Insight. Available at: http://www.chathamhouse.org.uk/files/16720_0610_froggatt_lahn.pdf

Anonymous (n.d.). Definitions of Risk. Business Dictionar. Available at: http://www.businessdictionary.com/definition/risk.html

Aragonés-Beltrán P., Pastor-Ferrando J.P., Chaparro-Gonzillez F., Bautista R.P. (2009). Selection of Photovoltaic Solar Power Plant Projects Unsing ANP. In: Proceedings of the International Symposium on the Analytic Hierarchy Process. Pittsburgh, Pennsylvania, USA. (p. 11). Available at: http://www.isahp.org/2009Proceedings/Final_Papers/

4_Aragones-Beltran_SOLAR_REV_FIN.pdf

Arhipova, I., Arhipovs, S. (2005). Riska vadības terminoloǵijas aspekti [Terminological aspects of risk monitoring]. Grām.: LLU raksti, Nr. 15(310) (3.-8. lpp.). Latvijas Lauksaimniecības universitāte. Jelgava.

Baoding L. (2011). Uncertainty Theory. Department of Mathematical Sciences. Available at: http://www.orsc.edu.cn/ liu/ut.pdf

Beck, U. (1999). What Is Globalization? Cambridge: Polity Press. 180 pp.

Ferraris, I., De la Canal, M.D., Labriola, C. (n.d.). Risk Analysis in Renewable Energy: Assessment of the Vulnerability of the Environment and Community. Available at: ttp://www.icrepq.com/icrepq07/363-ferraris.pdf

Froggatt, A., Lhan, G. (2010). Sustainable Energy Security. Strategic Risks and Oppurtunities for Business: White Paper. Lloyds $360^{\circ}$ risk insight. London: Chatman House. 48 pp.

Giddens, A. (2002). Runaway World. Croydon, Surrey: Bookmarque Ltd., pp. 6-20

Hardaker, J., Huirne, R.B.M., Anderson, J.R., Lien, G. (2004). Coping with Risk in Agriculture. Cambridge: CABI. 332 pp.

Leppälä, J., Murtonen, M., Suutarinen, J. (2008). Farm-RM — risk management tools for farms. NJF Report, 4(7), pp. 22-25.
Olivier, T., Consulting, A., Rödl \& Partner (n.d.). Scoping Study on Financial Risk Management Instruments for Renewable Energy Projects. United Nations Environment Programme. Reference document. Marsh and Mc Lennan Companies. 142 pp. Available at:

http://www.sefi.unep.org/fileadmin/media/sefi/docs/publications/ RiskMgt_full.pdf

Pettere, G., Voronova, I. (2003). Riski uznêemējdarbībā un to vadība [Risks in Entrepreneurship and Monitoring of Them]. Banku augstskola. Rīga: Rasa ABC. 176 lpp.

Rausser, G., Papineau, M. (2008). Managing R\&D Risk in Renewable Energy. University of California, Berkeley. Available at: http://escholarship.org/uc/item/41j9f6ks\#page-1

Renn, O. (2008). Concept of Risk: An Interdisciplinary Review. In: Proceedings of the ISA Conference, Barcelona, September 2008 (pp. 3-10). Available at:

http://www.riskanduncertainty.net/TG04/Ortwin_Renn_concepts.pdf

Rivža, P. (2004). Riska faktoru izvērtēšana un riska vadība Latvijas lauksaimniecībā [Evaluation of risk factors and risk monitoring in Latvian agriculture]. Grām.: LLU raksti. Nr. 11. Latvijas Lauksaimniecības universitāte (3.-8. lpp.). Jelgava (in Latvian).

Rivža, S., Rivža, P. (2011). Risk Assessment in Renewable Energy Production Using ANP: Proceedings of the $11^{\text {th }}$ International Symposium of the Analytic Hierarchy Process, Naples, Italy, 2011. Available at: http://204.202.238.22/isahp2011/dati/pdf/135_0176_Rivza.pdf

Saaty, T.L. (1999). Fundamentals of the Analytic Network Process. In: Proceedings of the International Symposium on the Analytic Hierarchy Process. Kobe, Japan. p. 14. Available at:

http://ergonomia.ioz.pwr.wroc.pl/download/AnpSaaty.pdf

Saaty, T.L. (2001). Decision making with dependence and feedback. In: The Analytic Network Process. Pittsburgh, PA: RWS Publications. 370 pp.

Saaty, T.L. (2010). Principia Mathematica Decernendi: Mathematical Principles of Decision Making. Pittsburgh, PA: RWS Publications. 531 pp.

Sparrow, A. (2000). A theoretical framework for operational risk management and opportunity realisation. New Zealand Treasury Working Paper 00/10. New Zealand Treasury, p. 31. Available at:

http://www.treasury.govt.nz/publications/research-policy/wp/ 2000/00-10/twp00-10.pdf

Špoğis, K. (2005). Risku ekonomiskās iespējas vai draudi un to seku novērtēšana [Economic opportunities or threats of risks and evaluation of their consequences]. Grām.: Riski lauksaimniecībā un privātajā mežsaimniecībā (385.-389. lpp.). Rivža, P. (red.). Jelgava: Latvijas Lauksaimniecības universitāte.

Šuškeviča, J. (2005). Riska vadības rokasgrāmata [Guide in Risk Monitoring]. Rīga: Dienas bizness, 12.-38. lpp.

Trigilio S. (2006). Applying the Principles of Risk Managament to Nuclear Plant Safety International Foundation for Protection Officers. 12 pp. Available at:

http://www.ifpo.org/articlebank/Trigilio_Nuclear_Power.pdf

Received 21 March 2012

\section{RISKA NOVĒRTĒJUMS ATJAUNOJAMĀS ENERG̣IJAS RAŽOŠANĀ NO LAUKSAIMNIECĪBAS IZCELSMES BIOMASAS LATVIJĀ}

Jēdzieni „risks”, „krīze”, „,briesmas” bieži un plaši tiek lietoti uzṇēmējdarbībā, valsts pārvaldē, lauksaimniecībā un vides aizsardzībā. Risku vadībai un risku novērtēšanai mūsdienās ir ne tikai teorētisks, bet arī praktisks pielietojums. Risku vadīšana ir būtisks faktors veiksmīgai un ilgtspējīgai uzṇēmējdarbībai atjaunojamās enerğijas ražošanā, kas ir kḷuvusi par vienu no Latvijas enerğêtikas sektora prioritātēm, turklāt atjaunojamās enerğijas izmantošanas veicināšana ir izvirzìta starp stratēgiskajiem mērkiem Eiropas Savienībā un Latvijā. Šajā rakstā atspoguḷotais pētījums fokusējas uz risku novērtējumu un risku vadības alternatīvu izvēli atjaunojamās enerğijas ražošanā no lauksaimniecības izcelsmes biomasas, kas tiek uzskatīta par perspektīvu resursu atjaunojamās enerǵijas ražošanai Latvijā. Tā kā šis enerǵijas ražošanas veids Latvijā ir samērā jauns un maz pētīts, pastāv daudzi riska faktori, kas ietekmē enerǵijas ražošanu, sākot ar reaktora projektēšanu un būvniecību un beidzot ar ražošanu un tālāku enerǵijas izmantošanu un sadali. Risku vadības alternatīvu modelis atjaunojamās enerğijas ražošanai no lauksaimniecības biomasas ir sagatavots, izmantojot tīklu analīzes metodi. 